九州大学学術情報リポジトリ

Kyushu University Institutional Repository

\title{
Lab-Scale Study of Desiccant Dehumidification System for Poultry Shed Air-Conditioning in Pakistan
}

\section{Aleem, Muhammad}

Department of Agricultural Engineering, Bahauddin Zakariya University

Hussain, Ghulam

Department of Agricultural Engineering, Bahauddin Zakariya University

Sultan, Muhammad

Department of Agricultural Engineering, Bahauddin Zakariya University

Miyazaki, Takahiko

Faculty of Engineering Sciences, Kyushu University

https://doi.org/10.5109/4102470

出版情報: Proceedings of International Exchange and Innovation Conference on Engineering \& Sciences (IEICES). 6, pp.85-91, 2020-10-22. Interdisciplinary Graduate School of Engineering Sciences, Kyushu University

バージョン：

権利関係 : 


\title{
Lab-Scale Study of Desiccant Dehumidification System for Poultry Shed Air-Conditioning in Pakistan
}

\author{
Muhammad Aleem ${ }^{1}$, Ghulam Hussain ${ }^{1,2}$, Muhammad Sultan $^{1, *}$, Takahiko Miyazaki $^{3}$ \\ ${ }^{1}$ Department of Agricultural Engineering, Bahauddin Zakariya University, Multan 60800, Pakistan \\ ${ }^{2}$ Agricultural Mechanization Research Institute (AMRI), Old Shujabad Road, Multan, Pakistan \\ ${ }^{3}$ Faculty of Engineering Sciences, Kyushu University, Kasuga-koen 6-1, Kasuga-shi, Fukuoka 816-8580, Japan. \\ *Corresponding author email: muhammadsultan@bzu.edu.pk
}

\begin{abstract}
Poultry sector is a major contributor in GDP of Pakistan. Poultry birds are highly sensitive to ambient temperature and relative humidity. At higher temperature and humidity ranges, poultry birds face heat stroke and suffocation. Thereby, a dedicated air-conditioning system for poultry birds is mandatory. In this regard, performance of low-cost desiccant dehumidification system coupled with Maisotsenko cycle evaporative cooling (M-DAC) system is experimentally analyzed for potential application of poultry birds air-conditioning. Thermodynamic performance of $M$ $D A C$ system is analyzed in terms of slope (i.e. $\phi^{*}=0.22$ ) and effectiveness $(\varepsilon)$. Thermal comfort of poultry birds in terms of temperature humidity index (THI) is assessed using ambient data of Multan (Pakistan) and process air conditions. MDAC system was found to be effective (in terms of THI) for poultry birds air-conditioning around the year especially in hot summer months (i.e. May, June July, August, and September) when THI for ambient air exceeded beyond permissible limit.
\end{abstract}

Keywords: Desiccant dehumidification; poultry sheds; experiments; Maisotsenko cycle; THI evaluation

\section{INTRODUCTION}

Livestock play a significant role in the economies of developing countries. As indicated by economic study of Pakistan, livestock sector share about $60.5 \%$ to overall agriculture and 11.2\% GDP throughout 2018-2019. Poultry sector is the most dynamic subsector of the livestock sector. The current devotion to the poultry business is above Rs. 700 billion. Pakistan form into eleventh biggest poultry maker in everywhere throughout the world with the creation of 1,163 million broilers for every annum. Poultry meat share 34\% (1,518 thousand tons) of the total meat production $(4,478$ thousand tons) in the country. Poultry sector has contributed $1.4 \%$ in all out GDP [1]. The comparison of poultry meat production with the human population is shown in Fig. 1. It is clear from figure that with increase in human population, the poultry meat production increases. It means the demand of food or meat increases with the increase in human population. Therefore, there should be predictive measures to enhance the poultry meat production. The production could be enhanced by controlling the thermal parameters that include temperature and relative humidity $[2,3]$

Temperature and humidity control are very essential for sustainable poultry production. High humidity caused fungal disease in the poultry because of aspergillosis. Aspergillosis is a non-endemic respiratory disease produce through a fungal species known as aspergillus. Aspergillosis chiefly affect the respiratory system of infected birds, invading the trachea, air sacs and lungs. In chicks, the disease mostly yields in acute form and in very relentless outbreaks that may kill about $70-90 \%$ within 24-48h of infection of the birds [4]. The acute form appears when large number of spores absorb by the bird. In adult chicks, the chronic form is mostly desultory with lesser mortality and weakened immune system [5]. The fungal disease effect due to aspergillosis is shown in
Fig. 2. High ambient temperatures have a major impact on anatomy and immune system of poultry birds that introduce inimical consequences to bird's productivity [6].

$\mathrm{AC}$ is a process that control temperature and humidity of control environment at the same time. Conventional vapor compression air conditioning (VCAC) systems are used for temperature and humidity control. The drawbacks of conventional VCAC systems like environmental degradation, more energy utilization [7]. In addition the VCAC systems consume $30 \%$ to $40 \%$ energy in buildings in all over the world $[8,9]$. Therefore, there is need of low energy driven technologies like Direct evaporative cooling (DEC), Indirect evaporative cooling, Maisotsenko cycle based indirect evaporative cooling (MEC). DEC system currently used in Pakistan to provide cool environment in poultry farms. In direct evaporative cooling the air is cooled by continuously evaporation of water. The disadvantages of DEC system center mainly on the refusal impact of too much humidification that increases risks of algae growth. As the humidity increases the effectiveness of bird's internal cooling system (panting) decreases [10]. IEC system follows an sensible cooling technique (i.e. without change in humidity ratio)[11]. The IEC systems are currently used in Pakistan in poultry farms to provide the cool air for their comfort zones. But the limitations of the IEC systems are (i) low effectiveness as compared to DEC (ii) no change in humidity ratio, that's why if the climatic condition have high humidity IEC system couldn't be feasible for poultry birds [12]. MEC system is a modified version of IEC. In this system the ambient air follows an thermodynamic process in which the renewable energy produced from air is utilized for the cooling of temperature [13,14].

Desiccant air conditioning (DAC) system is the process in which the dehumidification for humidity control and 
evaporative cooling for cooling purpose takes place simultaneously. Desiccant used in the DAC system is the hygroscopic material in which water vapor absorbed due to the vapor pressure difference between the surrounding air and the material. The DAC systems are environment friendly energy and efficient systems that reduces the energy consumption 5\% for heating and 30\% for cooling [15]. DAC systems deals sensible and latent load simultaneously that makes the DAC systems efficient and flexible. DAC systems are widely used in the areas where the humidity in the air is high [16]. There are also many general applications of DAC systems which include agriculture product storage, green house $\mathrm{AC}$, livestock AC [3,17-21], drying system of agriculture product storage [22]. Now a days M-cycle based DAC (M-DAC) systems are getting interest by researchers for humid climatic condition regions [23,24]. M-DAC system handles latent and sensible load simultaneously. The objective of present study is to develop the lab scale silica-gel based DAC system, evaluate the performance of experimental apparatus silica-gel based DAC system and investigate the applicability of standalone and Maisotsenko cycle evaporative cooling assisted DAC system for poultry air conditioning in Multan (Pakistan). Performance of M-DAC system for poultry air conditioning was assessed in terms of temperature humidity index (THI).

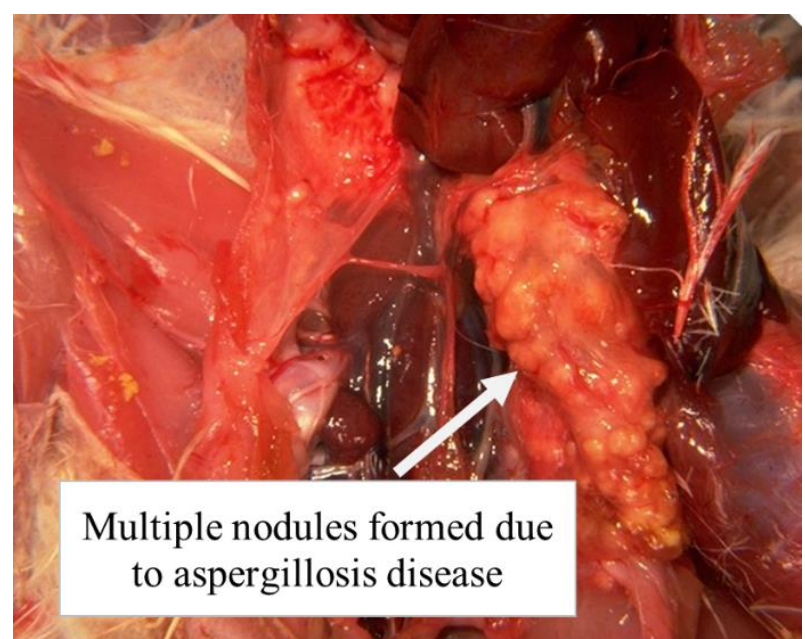

Fig. 1. Multiples nodules formation due to aspergillosis [25].

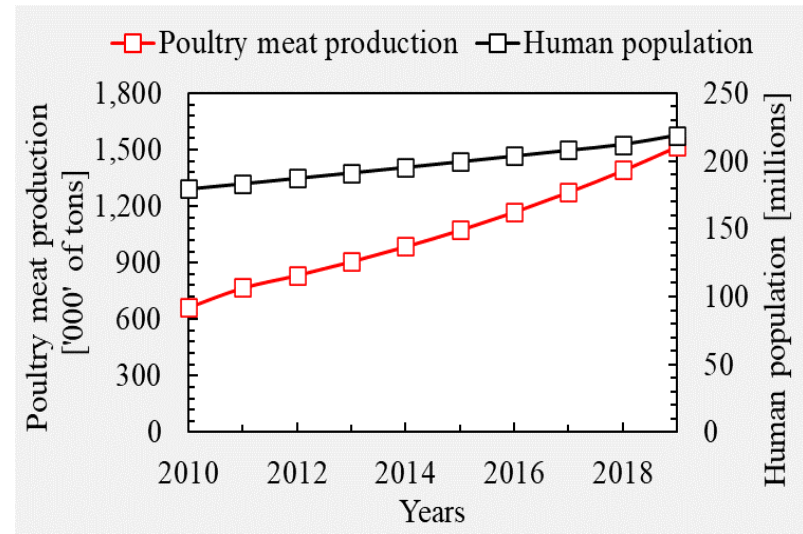

Fig. 2. Poultry population growth in Pakistan for year 2010-2019.

\section{MATERIALS AND METHODS}

\subsection{Experimental Section}

An open-cycle desiccant experiment system was setup. It consisted of a heater, fan, desiccant material, accessories, sieves, anemometer (BENETECH, GM816) with an accuracy of $\pm 1.5 \mathrm{~m} / \mathrm{s}(5 \%)$ and range of $0.3-30 \mathrm{~m} / \mathrm{s}$, temperature sensor (UNI-T, UT330A) with an accuracy $\pm 2{ }^{\circ} \mathrm{C}(1.6 \%)$ and range $-40-80{ }^{\circ} \mathrm{C}$, relative humidity sensor (UNI-T, UT330A) with an accuracy of $\pm 5 \%(5 \%)$ and range $0-100 \%$, pressure sensor (UNI-T, UT330A) with an accuracy of $\pm 3 \mathrm{hpa}(0.8 \%)$ and range 750 $1100 \mathrm{hPa}$ respectively. An important component of the desiccant system is sieves because of the desiccant material place on it. Sieves are contrived with polyacrylic material and mesh. A total of 18 sieves are used for the desiccant system and were kept on each in the shape of a rectangular block. Each sieve has a dimension of $250 \mathrm{~mm}$ $\times 145 \mathrm{~mm} \times 3 \mathrm{~mm}$ and about $68 \mathrm{~g}$ of silica gel is placed over each sieve. Total silica gel used for this experiment about $1.22 \mathrm{~kg}$.

The experimental procedure of DAC system is that the ambient air enters in the desiccant unit and converts into dry and hot because of release of the heat of adsorption. Later, the desiccant material becomes saturated by moisture absorbed during dehumidification process. Therefore, the regeneration process is done to provide the regeneration stream for regeneration of desiccant material for completion of cycle. Schematic diagram of the experimental apparatus of silica-gel based DAC system is shown in Fig. 3. The regeneration temperature was set at $60^{\circ} \mathrm{C}$ and $70^{\circ} \mathrm{C}$. The air mass flow rate that passed through the desiccant unit is about $0.05 \mathrm{~kg} / \mathrm{s}$ to $0.008 \mathrm{~kg} / \mathrm{s}$.

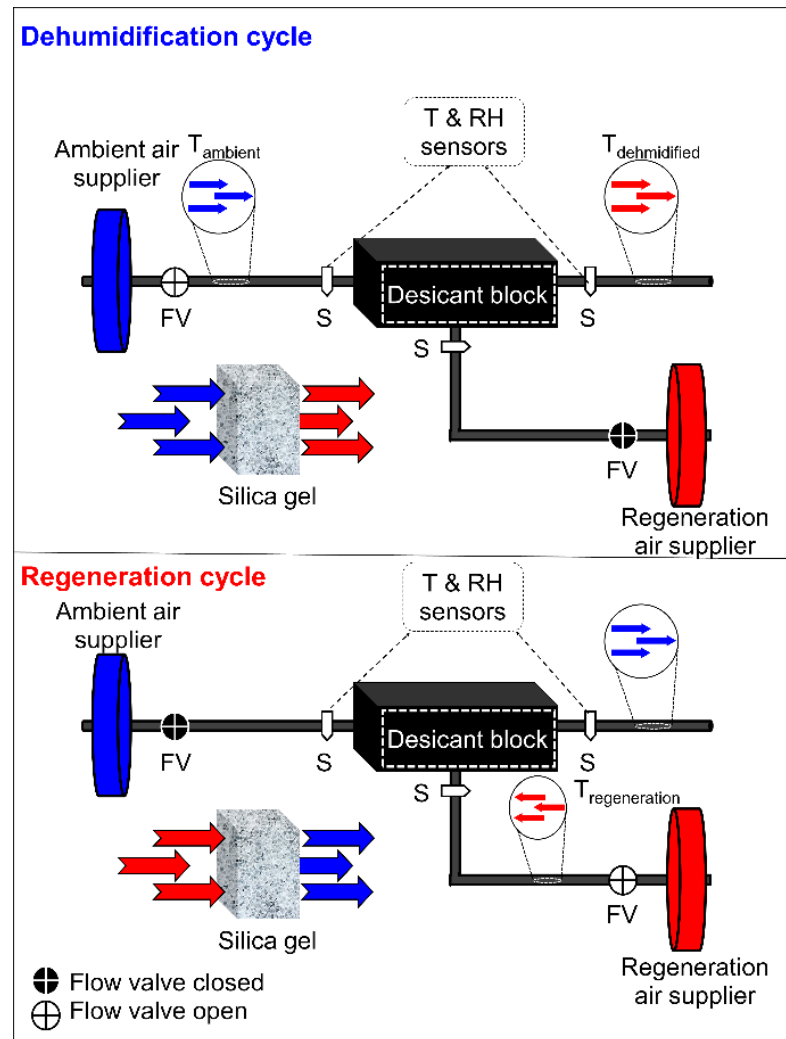

Fig. 3. Schematic representation of experimental DAC system. 


\subsection{Research Methodology}

To investigate the performance of silica-gel based DAC system an open cycle experimental apparatus was established. This experimental apparatus provides us statistics of desiccant dehumidification. The desiccant absorbent shows the absorbing nature to ingest the moisture due to the vapor pressure difference between the ambient air and absorbent calculated by equation (1) [26] By using the dehumidification statistics, the relationship is developed called slope of dehumidification line on the psychrometric chart. The slope of dehumidification line during dehumidification process follows an isenthalpic behavior, ideally. But experimentally, the net adsorption is heat is greater than the ideal adsorption heat because of isosteric heat of adsorption [27]. The slope of dehumidification line is calculated by an equation (2) [26]. The Ambient air enters in the desiccant unit and dehumidification (condition 1 to 2 ) takes place which results in decrease in relative humidity and increase in temperature of the air. Later, the dehumidified air goes through the heat exchanger (HX) and M-cycle cooling device is calculated by equation (3-4). The relevant work to utilize potential of dehumidification has been discussed [28]. The regeneration is required for desorbing the desiccant material to complete the cycle. The regeneration condition 6 is calculated by equation (5) $[3,29]$.

$$
\begin{aligned}
& \Delta X=X_{\text {in }}-X_{\text {out }} \\
& \phi^{*}=\frac{X_{\text {in }}-X_{\text {out }}}{T_{\text {out }}-T_{\text {in }}} \\
& T_{3, d b}=T_{2, d b}-\varepsilon_{H X}\left(T_{2, d b}-T_{5, d b}\right) \\
& T_{4, d b}=T_{3, d b}-\varepsilon_{w b}\left(T_{3, d b}-T_{1, w b}\right) \\
& T_{6, d b}=T_{5, d b}-\varepsilon_{H X}\left(T_{2, d b}-T_{5, d b}\right) \\
& X_{1}=X_{5}=X_{6}=X_{7} \\
& X_{2}=X_{3}=X_{4}
\end{aligned}
$$

Optimum temperature and relative humidity are mandatory for efficient production of poultry birds. The ideal temperature $\left(34-20^{\circ} \mathrm{C}\right)$ and relative humidity (50$70 \%$ ) zones throughout the growth period are shown in Fig. 4 [30,31]. The birds grow their tissues, muscles due to feed intake. The heat is produced after digestion of feed and because of this more heat is released [32]. Therefore, the heat production by poultry birds and their temperature humidity index (THI) is necessary for design cooling load of AC systems. The rate of heat production by poultry birds vary with age and weight [33]. The weight gain with respect to age is calculated by equation (9) [34]. The sensible and total heat production in poultry birds with respect to days is calculated by equation (1011) $[35,36]$ respectively. THI's linear relationship with dry bulb and wet bulb temperature is calculate by equation (12) [37].

$$
\begin{aligned}
& W_{b}=f_{1} \cdot d^{3}+f_{2} \cdot d^{2}+f_{3} \cdot d+f_{4} \\
& q_{T}=9.84 m_{a}^{0.75}\left(4 e^{-5}\left(20-T_{d b}\right)^{3}+1\right) \\
& q_{S}=0.83 q_{T}\left(0.8-1.85 e^{-7}\left(T_{d b}+10\right)^{4}\right) \\
& T H I=0.85 T_{d b}+0.15 T_{w b}
\end{aligned}
$$

Where, the subscript 1-7 and 'in' 'out' are the conditions shown in Fig. 4. $X, \phi_{d e h}$ and $\phi_{h}, T, d b, T, w b, \varepsilon_{H X}, \varepsilon_{w b}$,
$\mathrm{W}_{\mathrm{b}}, \mathrm{d}, \mathrm{f}_{1}, \mathrm{f}_{2}, \mathrm{f}_{3}, \mathrm{f}_{4}, \mathrm{q}_{\mathrm{T}}, \mathrm{q}_{\mathrm{s}}, \mathrm{m}_{\mathrm{a}}$, THI indicates the humidity ratio $\left(g_{w} / \mathrm{kg}-\mathrm{DA}\right)$; is the mass flow rate of air $[\mathrm{kg} / \mathrm{s}]$; represent the slope of dehumidification line [-] and slope of enthalpy line [-]; dry bulb temperature $\left[{ }^{\circ} \mathrm{C}\right]$; wet bulb temperature $\left[{ }^{\circ} \mathrm{C}\right]$; are the effectiveness of heat exchanger (HX) and wet bulb of M-cycle indirect evaporative cooling taken as 0.9 and 0.6 [3]; bird live weight [kg]; birds age [days]; are the coefficients available in Table 1 ; total heat production $[\mathrm{j} / \mathrm{s}]$; sensible heat production $[\mathrm{j} / \mathrm{s}]$; mass of bird $[\mathrm{kg}]$ temperature humidity index $9\left[{ }^{\circ} \mathrm{C}\right]$ respectively.

Table 1. Coefficients for calculation of weight gain of poultry birds with respect to days

\begin{tabular}{ccc}
\hline Coefficients & Value & Unit \\
\hline$f_{1}$ & $-2.1164 \times 10^{-5}$ & $\left(\mathrm{~kg} \cdot \mathrm{day}^{-3}\right)$ \\
$f_{2}$ & $+2.5608 \times 10^{-3}$ & $\left(\mathrm{~kg} \cdot \mathrm{day}^{-2}\right)$ \\
$f_{3}$ & $-5.3002 \times 10^{-3}$ & $\left(\mathrm{~kg} \cdot \mathrm{day}^{-1}\right)$ \\
$f_{4}$ & $+7.0839 \times 10^{-2}$ & $(\mathrm{~kg})$
\end{tabular}

\section{PROPOSED SYSTEMS}

In this study, the standalone and M-cycle based DAC systems are proposed for the potential poultry application. The performance assessment of these proposed system is analyzed for the climatic condition of Multan (Pakistan). A summary of the proposed DAC system is given below.

\subsection{Standalone DAC system}

Dedicated standalone desiccant air-conditioning system (DAC) comprised of solid desiccant silica gel-based dehumidification unit coupled with sensible heat exchanger. Ambient air passes through desiccant block, which dehumidifies the air and slightly increases its temperature near to the regeneration temperature of the desiccant block (condition 1-2). Furthermore, hot, and dehumidified air passes through sensible heat mass exchanger which somewhat reduces the temperature of the air without affecting the humidity ratio (condition 3 ). Ambient air conditions are used for regeneration of desiccant block. Ambient air is passed through heat exchanger as a return air which transfer the heat of process air into the regeneration air, slightly raising its temperature without affecting the humidity ratio (6). The regeneration air passes through a low-grade heating source (preferably solar collector, but biomass, waste heat from processes can also be used) which further increases the temperature of the regeneration air. This hot and relatively dry regeneration air passes through desiccant block which desorbs the solid desiccant (i.e. silica gel) and absorbs its moisture, transferring the sensible heat into the desiccant unit which is then transferred to the process air (condition 7), hence completing the cycle.

\subsection{M-cycle based DAC system}

Dedicated M-cycle based desiccant air-conditioning system (M-DAC) comprised of solid desiccant silica gelbased dehumidification unit joined with sensible heat exchanger. Ambient air passes through desiccant block, which dehumidifies the air and slightly increases its temperature near to the regeneration temperature of the desiccant block (condition 1-2). Likewise, hot, and dehumidified air passes through sensible heat mass exchanger which slightly reduces the temperature of the 
air without affecting the humidity ratio (condition 3 ). After that, this process air passes through the M-cycle cooling device and decreases the temperature to the ambient air, ideally (condition 4). Ambient air conditions are intended for regeneration of desiccant block. Ambient air is gone through heat exchanger as a return air which transfer the heat of process air into the regeneration air, slightly increasing its temperature without influencing the humidity ratio (6). The schematic diagram of proposed M-DAC system is shown in Fig. 4. The regeneration air passes through a low-grade heating source (preferably solar collector, but biomass, waste heat from processes can also be used) which further increases the temperature of the regeneration air (condition 7). This hot and relatively dry regeneration air passes through desiccant block which desorbs the solid desiccant (i.e. silica gel) and absorbs its moisture, transferring the sensible heat into the desiccant unit which is then transferred to the process air (condition 8), hence completing the cycle.

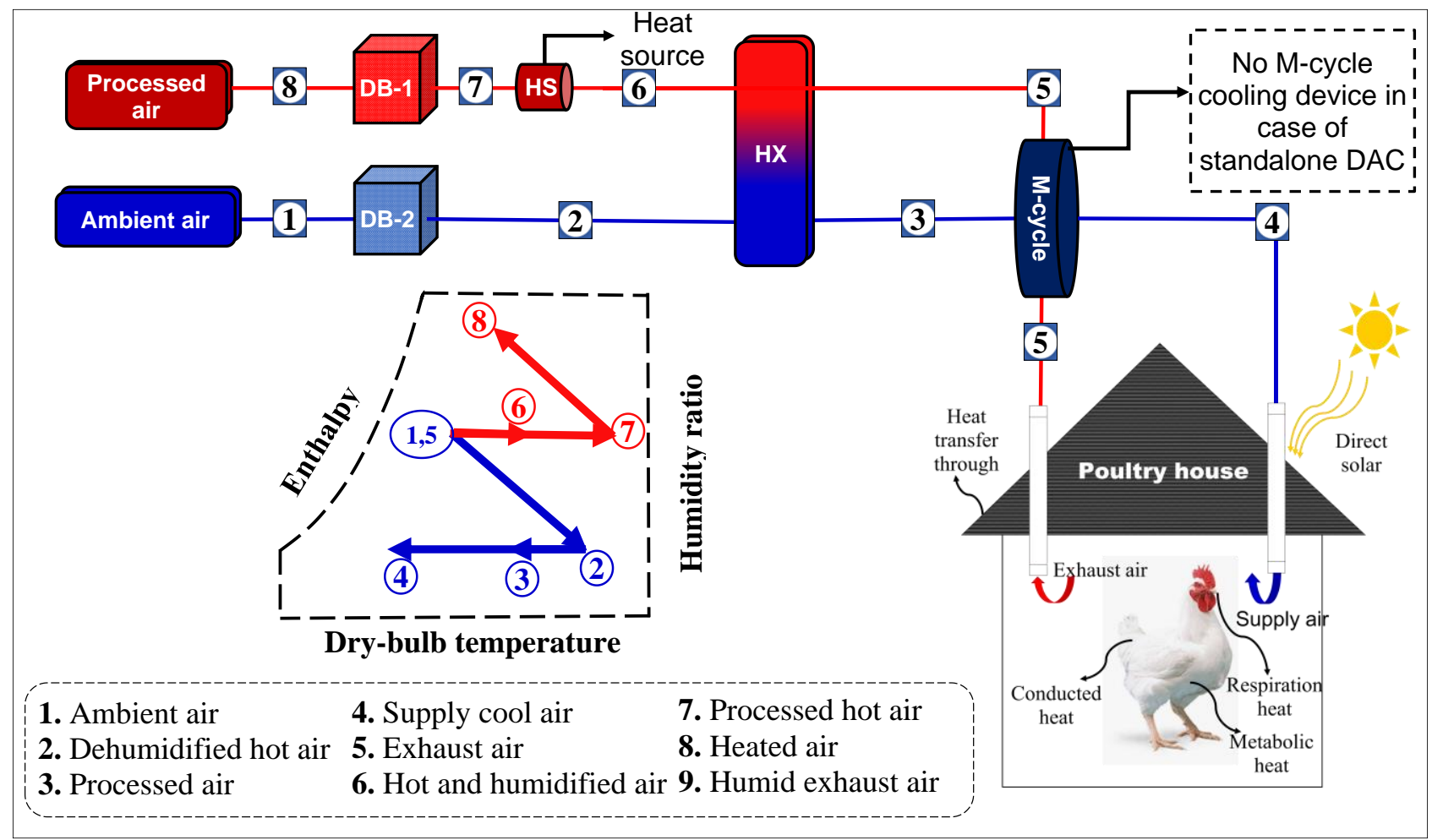

Fig. 4. Schematic representation of proposed M-DAC system.

\section{RESULTS AND DISCUSSION}

The performance of the silica-gel based DAC system is assessed experimentally. Fig. 5 shows the experimental profile for the climatic condition of Multan, Pakistan.

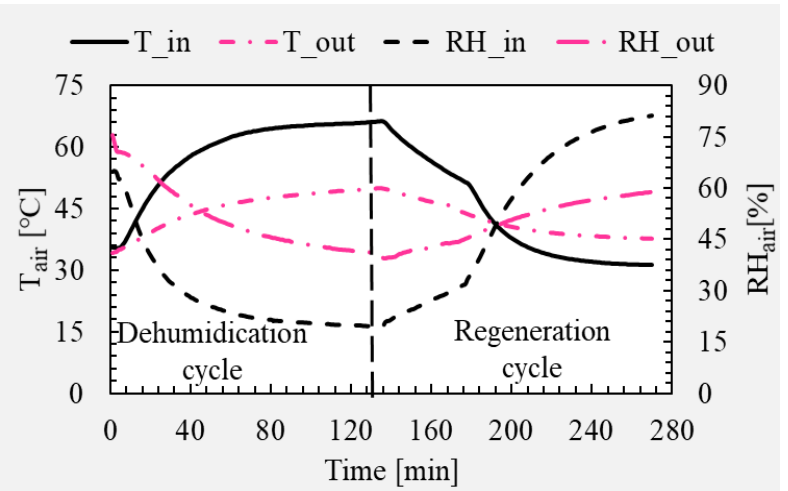

Fig. 5. Experimental profile of ambient air condition of Multan with desiccant dehumidification at regeneration temperature of $65^{\circ} \mathrm{C}$.

This indicates the dynamic nature of process and the regeneration temperature of $65^{\circ} \mathrm{C}$. It is clear from the figure that after 180 minutes the surrounding air enters the desiccant at 50-80\% relative humidity and departure at $48 \%$ to $59 \%$ that reveals the potential of dehumidification achieved through the experimental system.

The slope of experimental dehumidification is shown in Fig. 6. It reveals that the slope of dehumidification does not vary significantly up to 60 minutes. Therefore, the $\phi^{*}$ $=0.22$ will be used for the simulating the desiccant dehumidification of the desiccant system.

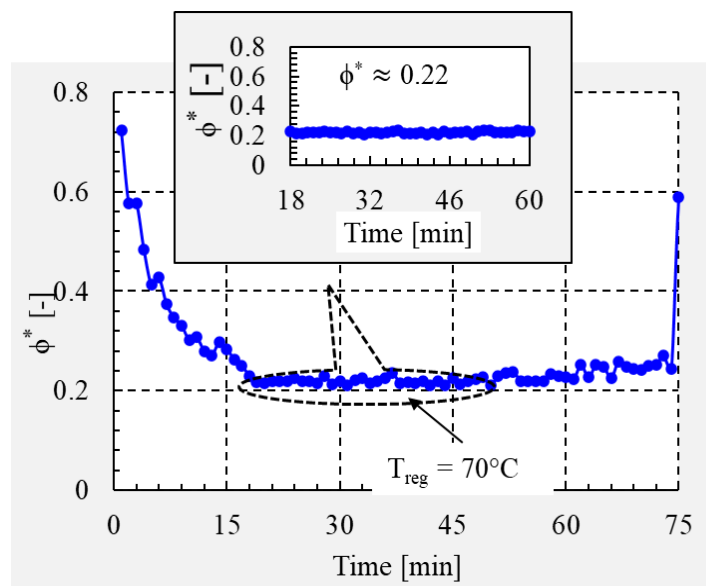

Fig. 6. Experimental investigation of the slope of dehumidification line at $70^{\circ} \mathrm{C}$ regeneration temperature. 
Additionally, this slope $\left(\phi^{*}=0.22\right)$ has been utilized for dehumidification of climatic condition of Multan, Pakistan for the performance assessment of standalone and M-cycle aided DAC system for poultry application. Fig. 7(a) and 7(b) shows the monthly based analysis of standalone and M-cycle based DAC systems, respectively. The temperature and relative humidity profile on monthly based are displayed in Fig. 7.

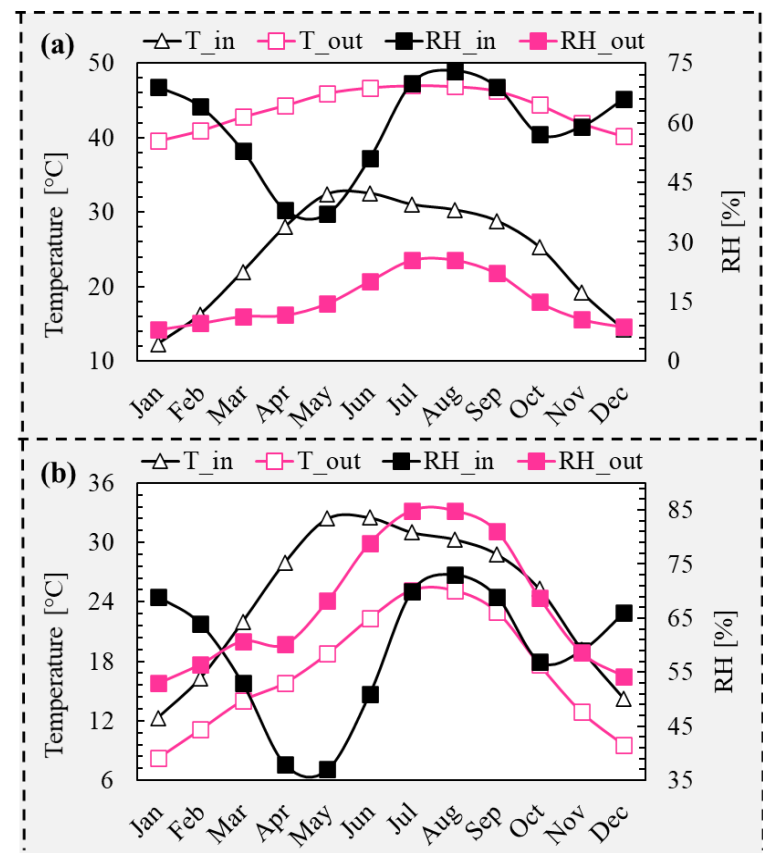

Fig. 7. Monthly based temperature and relative humidity profile of (a) standalone DAC system (b) M-cycle based DAC system for climatic condition of Multan.

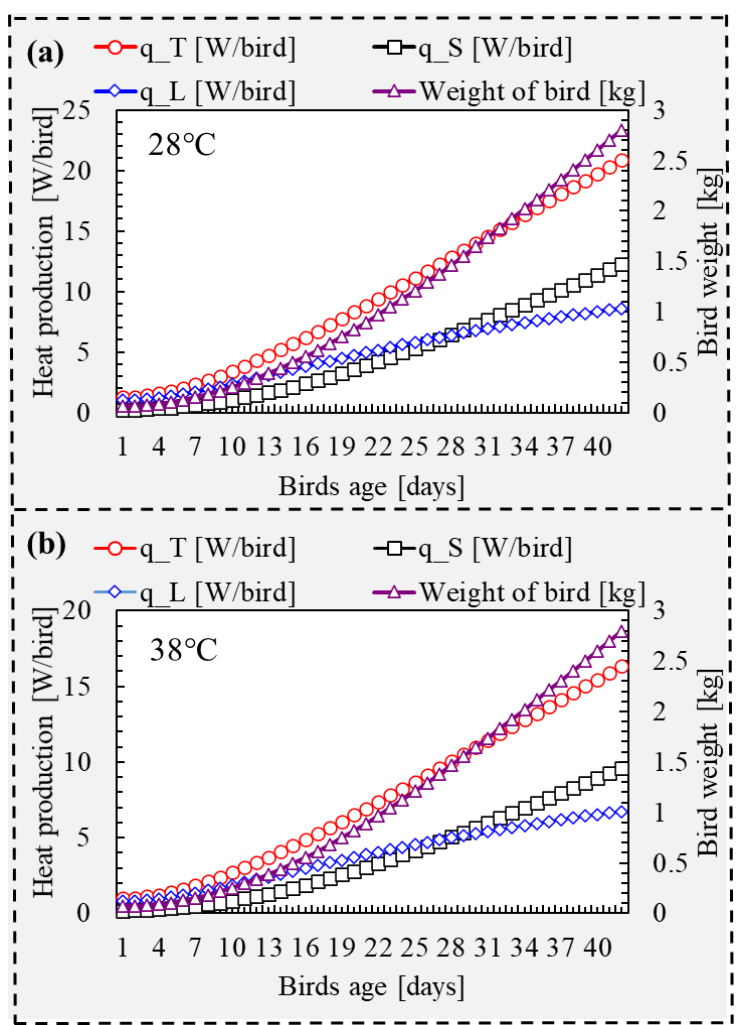

Fig. 8. Total, sensible, and latent heat production for poultry birds with respect to age and weight at (a) $28^{\circ} \mathrm{C}$ (b) $38^{\circ} \mathrm{C}$.
The total heat production (sensible, latent) by poultry bird with respect to age and weight at $28^{\circ} \mathrm{C}$ and $38^{\circ} \mathrm{C}$ are presented in Fig. 8(a) and 8(b) respectively. It is seen that the total heat production by poultry birds increases with respect to age and weight. Fig. 8(a) shows that at $2.8 \mathrm{~kg}$ bird live weight the total heat production is $20 \mathrm{~J} / \mathrm{s}$ at $28^{\circ} \mathrm{C}$. Fig. 8(b) shows that the at $2.8 \mathrm{~kg}$ bird live weight at $42^{\text {nd }}$ day of growth the total heat production is $16 \mathrm{~J} / \mathrm{s}$ at $38^{\circ} \mathrm{C}$. The heat produced by poultry bird at $38^{\circ} \mathrm{C}$ is less as compared to $28^{\circ} \mathrm{C}$ because at high outside temperature the poultry birds could not release the heat from their body. Moreover, THI is on monthly basis for standalone and M-cycle based DAC systems is displayed in Fig.9. The permissible limit of THI for poultry birds for their optimum production is less than $30^{\circ} \mathrm{C}$. Hence, it is seen that the THI for standalone DAC system is above $30^{\circ} \mathrm{C}$ throughout the year. Likewise, the THI for M-cycle based DAC system is in permissible range of THI $\left(<30^{\circ} \mathrm{C}\right)$ throughout the year.

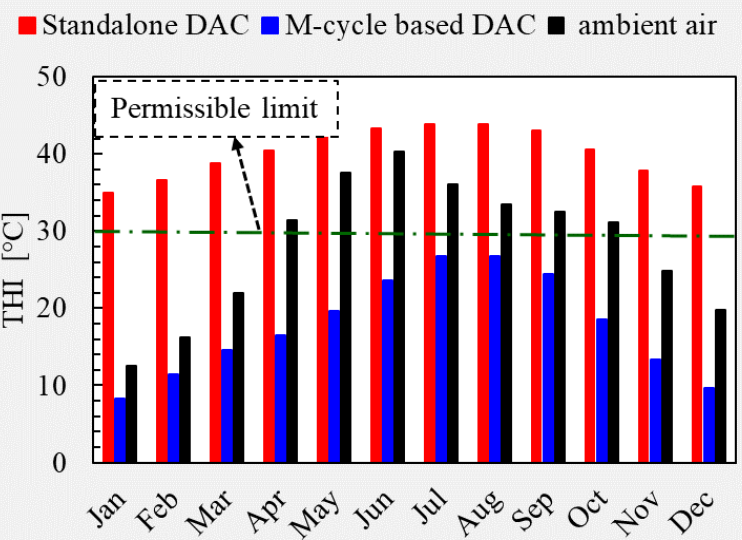

Fig. 9. Monthly based temperature humidity index (THI) profile.

\section{CONCLUSIONS}

In current study, silica gel based desiccant air conditioning system coupled with Maisotsenko cycle evaporative cooling system was thermodynamically analyzed for potential application of poultry air conditioning. Performance of the solid desiccant air conditioning system was analyzed at different regeneration temperature. Slope $\left(\phi^{*}=0.22\right)$ method was used to analyze the performance of desiccant air conditioning system. Performance of the advanced indirect evaporative cooler (i.e. Maisotsenko cycle evaporative cooling system) was analyzed using effectiveness method. Thereby, coupled effect of desiccant air conditioning system and Maisotsenko cycle evaporative cooling system on ambient air was observed for poultry air conditioning for the climatic conditions of Multan (Pakistan). The results concluded that temperature and humidity index (THI) calculation of poultry birds for their thermal comfort is in permissible range by adopting Maisotsenko cycle evaporative cooling-based DAC system throughout the year.

\section{Acknowledgements}

All this work is part of the Ph.D. research of Mr. Ghulam Hussain. This research work has been carried out in the Department of Agricultural Engineering, Bahauddin Zakariya University, Multan-Pakistan. This research was funded by Bahauddin Zakariya University, 
Multan-Pakistan under the Director Research/ ORIC grant titled "Thermodynamic evaluation of low-cost airconditioning systems for various applications" awarded to Principal Investigator: Dr. Muhammad Sultan.

\section{Conflict of interest}

The authors declare no conflict of interest.

\section{REFERENCES}

[1] Ministry of Finance. Pakistan Economic Survey (accessed July 31, 2020).

[2] Sultan M, Miyazaki T, Saha BB, Koyama S. Steady-state investigation of water vapor adsorption for thermally driven adsorption based greenhouse air-conditioning system. Renew Energy 2016;86:785-95. https://doi.org/10.1016/j.renene.2015.09.015.

[3] Sultan M, Miyazaki T, Koyama S, Khan ZM. Performance evaluation of hydrophilic organic polymer sorbents for desiccant air-conditioning applications. Adsorpt Sci Technol 2018;36:31126. https://doi.org/10.1177/0263617417692338.

[4] Dhama K, Chakraborty S, Verma AK, Tiwari R, Barathidasan R, Kumar A, et al. Fungal/mycotic diseases of poultry-diagnosis, treatment and control: A review. Pakistan J Biol Sci 2013;16:1626-40. https://doi.org/10.3923/pjbs.2013.1626.1640.

[5] Girma G, Abebaw M, Zemene M, Mamuye Y. A Review on Aspergillosis in Poultry. J Vet Sci Technol 2016;07. https://doi.org/10.4172/21577579.1000382 .

[6] Lara LJ, Rostagno MH. Impact of heat stress on poultry production. Animals 2013;3:356-69. https://doi.org/10.3390/ani3020356.

[7] Mahmood MH, Sultan M, Miyazaki T, Koyama S. Desiccant air-conditioning system for storage of fruits and vegetables: Pakistan preview. Evergreen 2016;3:12-7. https://doi.org/10.5109/1657381.

[8] Caliskan H, Dincer I, Hepbasli A. Exergetic and sustainability performance comparison of novel and conventional air cooling systems for building applications. Energy Build 2011;43:1461-72. https://doi.org/10.1016/j.enbuild.2011.02.006.

[9] Tertipis D, Rogdakis E. Maisotsenko cycle: technology overview and energy-saving potential in cooling systems. Energy Emiss Control Technol 2015:15. https://doi.org/10.2147/eect.s62995.

[10] Longstaff M. Poultry production in hot climates. vol. 61. 1996. https://doi.org/10.1016/03778401(95)00928-0.

[11] Duan Z, Zhan C, Zhang X, Mustafa M, Zhao X, Alimohammadisagvand $\mathrm{B}$, et al. Indirect evaporative cooling: Past, present and future potentials. Renew Sustain Energy Rev 2012;16:6823-50. https://doi.org/https://doi.org/10.1016/j.rser.201 2.07.007.

[12] Maheshwari GP, Al-Ragom F, Suri RK. Energy-saving potential of an indirect evaporative cooler. Appl Energy 2001;69:6976. https://doi.org/10.1016/S03062619(00)00066-0.
[13] Anisimov S, Pandelidis D. Numerical study of perforated indirect evaporative air cooler. Int J Energy a Clean Environ 2011;12:239-50. https://doi.org/10.1615/InterJEnerCleanEnv.201 3006668.

[14] Pandelidis D, Anisimov S, Worek WM. Comparison study of the counter-flow regenerative evaporative heat exchangers with numerical methods. Appl Therm Eng 2015;84:211-24. https://doi.org/https://doi.org/10.1016/j.applther maleng.2015.03.058.

[15] Nagaya K, Senbongi T, Li Y, Zheng J, Murakami I. High energy efficiency desiccant assisted automobile air-conditioner and its temperature and humidity control system. Appl Therm Eng 2006;26:1545-51. https://doi.org/10.1016/j.applthermaleng.2005.1 2.005.

[16] Sultan M, El-Sharkawy II, Miyazaki T, Saha BB, Koyama S. An overview of solid desiccant dehumidification and air conditioning systems. Renew Sustain Energy Rev 2015;46:16-29. https://doi.org/10.1016/j.rser.2015.02.038.

[17] Mahmood MH, Sultan M, Miyazaki T, Koyama S, Maisotsenko VS. Overview of the Maisotsenko cycle - A way towards dew point evaporative cooling. Renew Sustain Energy Rev 2016;66:537-55. https://doi.org/10.1016/j.rser.2016.08.022.

[18] Mahmood MH, Sultan M, Miyazaki T. Experimental evaluation of desiccant dehumidification and air-conditioning system for energy-efficient storage of dried fruits. Build Serv Eng Res Technol 2020;41:454-65. https://doi.org/10.1177/0143624419893660.

[19] Sultan M, Miyazaki T, Koyama S. Optimization of adsorption isotherm types for desiccant airconditioning applications. Renew Energy 2018;121:441-50. https://doi.org/10.1016/j.renene.2018.01.045.

[20] Sultan M, Miyazaki T, Mahmood MH, Khan ZM. Solar assisted evaporative cooling based passive air-conditioning system for agricultural and livestock applications. J Eng Sci Technol 2018;13:693-703.

[21] Kashif M, Niaz H, Sultan M, Miyazaki T, Feng Y, Usman M, et al. Study on desiccant and evaporative cooling systems for livestock thermal comfort: Theory and experiments. Energies 2020;13. https://doi.org/10.3390/en13112675.

[22] Hanif S, Sultan M, Miyazaki T, Koyama S. Steady-state investigation of desiccant drying system for agricultural applications. Evergreen 2018;5:33-42. https://doi.org/10.5109/1929728.

[23] Gao WZ, Cheng YP, Jiang AG, Liu T, Anderson K. Experimental investigation on integrated liquid desiccant - Indirect evaporative air cooling system utilizing the Maisotesenko - Cycle. Appl Therm Eng 2015;88:288-96. https://doi.org/https://doi.org/10.1016/j.applther maleng.2014.08.066.

[24] Amer O, Boukhanouf R, Ibrahim HG. A 
Review of Evaporative Cooling Technologies. Int J Environ Sci Dev 2015;6:111-7. https://doi.org/10.7763/ijesd.2015.v6.571.

[25] Poultry World. Aspergillosis (Brooder pneumonia) 2019.

https://www.poultryworld.net/Health/health_too 1/Aspergillosis/ (accessed July 31, 2020).

[26] Mahmood MH, Sultan M, Miyazaki T. Solid desiccant dehumidification-based airconditioning system for agricultural storage application: Theory and experiments. Proc Inst Mech Eng Part A J Power Energy 2020;234:534-47. https://doi.org/10.1177/0957650919869503.

[27] Sultan M, El-Sharkawy II, Miyazaki T, Saha BB, Koyama S, Maruyama T, et al. Water vapor sorption kinetics of polymer based sorbents: Theory and experiments. Appl Therm Eng 2016;106:192-202. https://doi.org/10.1016/j.applthermaleng.2016.0 5.192.

[28] Yaningsih I, Mahmood MH, Wijayanta AT, Miyazaki T, Koyama S. Experimental study on dehumidification technology using honeycomb desiccant block. Evergreen 2018;5:11-8. https://doi.org/10.5109/1936212.

[29] Sultan M, Miyazaki T. Energy-Efficient AirConditioning Systems for Nonhuman Applications. Refrigeration, InTech; 2017. https://doi.org/10.5772/intechopen.68865.

[30] Cândido MGL, Tinôco I de FF, Pinto F de A d. C, Santos NT, Roberti RP. Determination of thermal comfort zone for early-stage broilers. Eng Agric 2016;36:760-7. https://doi.org/10.1590/1809-4430Eng.Agric.v36n5p760-767/2016.

[31] Cassuce DC, Zolnier S, Cecon PR, Vieira MDEFA. Atualização da temperaturas de conforto térmico para frangos de corte de até 21 dias de idade. Eng Agrícola 2013;33:28-36. https://doi.org/10.1590/S010069162013000100004.

[32] R. S. Gates, H. Xin. Comparative Analysis of Measurement Techniques of Feeding Behavior of Individual Poultry 2013. https://doi.org/10.13031/2013.7452.

[33] Chepete HJ, Xin H, Puma MC, Gates RS. Heat and moisture production of poultry and their housing systems: Pullets and layers. ASHRAE Trans 2004;110 PART I:286-99.

[34] Costantino A, Fabrizio E, Ghiggini A, Bariani M. Climate control in broiler houses: A thermal model for the calculation of the energy use and indoor environmental conditions. Energy Build 2018;169:110-26. https://doi.org/10.1016/j.enbuild.2018.03.056.

[35] Pedersen S, Gaardbo Thomsen M. Heat and Moisture Production of Broilers kept on Straw Bedding. J Agric Eng Res 2000;75:177-87. https://doi.org/https://doi.org/10.1006/jaer.1999. 0497.

[36] Silva MP, Baêta FC, Tinôco IFF, Zolnier S, Ribeiro A. Evaluation of a simplified model for estimating energy balance in broilers production housing. Rev Bras Eng Agric e Ambient 2007;11:532-6. https://doi.org/10.1590/S141543662007000500014.

[37] Purswell JL, Dozier WA, Olanrewaju HA, Davis JD, Xin H, Gates RS. Effect of temperature-humidity index on live performance in broiler chickens grown from 49 to 63 days of age. ASABE - 9th Int Livest Environ Symp 2012, ILES 2012 2012;7004:419. 